\title{
Considerações sobre o homossexualismo no Brasil e no Congo
}

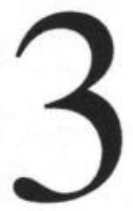

\section{RESUMO}

O presente trabalho, realizado através da observação de casos clínicos e de pesquisa bibliográfica, apresenta um breve estudo da questão homossexual na atualidade, em diferentes culturas, sob o ponto de vista religioso, político e psicopatológico. Os autores alertam para a necessidade de se repensar os conceitos nos três níveis citados, tomando-se como referência a lógica que orienta a estrutura social das diferentes culturas.

Observa-se que, na sociedade brasileira, aparentemente inserida no contexto da modernidade, as dificuldades de encontro do conhecimento científico com o conhecimento popular sobre o fenômeno da homossexualidade têm sido geradoras de sofrimento psíquico para os sujeitos envolvidos.

\footnotetext{
* Psicoterapeuta. Doutorando em Psicopatologia pela Universidade de Picardie Jules Verne. Professor na UNIVALE.

** Psicoterapeuta. Doutor em psicopatologia. Professor substituto. Pesquisador pela Universidade de Picardie Jules Verne.

*** Psicoterapeuta. Doutoranda em Psicologia pela Universidade de Picardie Jules Verne. Professora na UNILESTE-MG. e-mail: dias@wanadoo.jr Recebido em 01.09 .01 santusia@wanadoo.jr Aprovado em 20.09.01
} 
Também sociedades consideradas arcaicas por valorizarem antigas tradições, optam pela coesão grupal e, a partir de uma lógica interna do grupo, promovem a exclusão daqueles que se mostram diferentes.

Está evidente que as respostas às questões humanas não passam, compulsoriamente, pelo crivo da globalização. Considerando o fato de que o fenômeno psicopatológico reflete um "certo desequilíbrio" na estrutura que rege as relações entre os indivíduos em um dado grupo social, os autores propõem que a questão da homossexualidade seja avaliada sob o prisma da coerência cultural.

\section{INTRODUÇÃO}

O estudo de temas relativos à sexualidade humana, segundo uma abordagem psicopatológica e sociocultural é, ainda na atualidade, acompanhado de muitas dúvidas, sobretudo no que se refere às teorias apresentadas e às práticas dos sujeitos e dos grupos sociais.

Questões relativas à educação sexual de crianças e adolescentes, bem como quais práticas devem ser consideradas "adequadas", estão longe de atingirem um consenso. Então, a partir de nosso trabalho enquanto pesquisadores, fomos levados a formular a seguinte reflexão:

- Será que não estaríamos, mais uma vez, a espera de um "manual", de uma "cartilha", como é comum ao povo brasileiro, sobre como se deve viver a sexualidade "humana"? Afinal, quase sempre perdidos e acostumados a esperar "a coisa pronta", seria mais fácil buscar uma "receita" ou um "modo de fazer". É isso que estamos esperando? A compreensão da sexualidade humana, com toda sua complexidade e subjetividade (termos partidários e inseparáveis), torna-se na atualidade, mais imprescindível que nunca, para o exercício de uma prática sexual saudável. A esse respeito, temos observado que, sobretudo os temas relativos à homossexualidade, ainda se apresentam com muitas contradições.

Atualmente, as discussões sobre esse assunto têm se apresentado mais freqüentemente, segundo dois extremos: de um lado, constata-se que teóricos do comportamento humano se escondem por detrás de "jargões" e conceitos "científicos" complicados, dificultando o acesso (o tema ainda continua um "tabu" em muitos países) e a compreensão do comportamento homossexual; e de outro, encontraremos autores que anunciarão seus pontos de vista, de forma insistente, com o intuito de contestar ou de defender uma idéia pessoal. No primeiro caso, o excesso de zelo pode camuflar um medo de se posicionar com objetividade perante o tema, mesmo que esse posicionamento seja fundamentado em práticas científicas ou em experiências profissionais. No segundo caso, observa-se a presença de idéias "moralistas" que tentam esconder a realidade dos fatos, possivelmente, por medo da perda de um referencial cultural. Sujeitos que se mostram "partidários", "simpatizantes" e de uma forma um tanto "panfletária", tentam despertar 
numa sociedade intolerante, um falso respeito à liberdade individual de escolha, no que tange à vida sexual.

Embora a diversidade de opiniões em torno desse tema tenha sua origem na história de diferentes grupos sociais, parece-nos que o simples fato de os sujeitos tomarem consciência da história, da qual foram "feitos", não será suficiente para reduzir o sofrimento psíquico dos sujeitos concernentes. A intolerância, a discriminação e a dificuldade em aceitar a diferença no momento da escolha de um parceiro, têm sido, depois de séculos, origem de grande sofrimento. Tais sofrimentos são provocados pela exclusão, por agressões, prisões e até mortes, que tornam homossexuais, freqüentemente, vítimas e passíveis de todo tipo de humilhação. Observa-se, com naturalidade, o "lugar" de fragilidade, de baixa de sua auto-estima, de desproteção, de falta de referência, nos quais esses são obrigados a se "exilar".

Segundo nossas observações, existem dois fatores primários que tem dificultado as discussões e a compreensão sobre a identificação do sujeito homossexual, que ainda se apresenta como aquele que tem comportamentos ditos "perversos" e "ilegais".

Por questões de afinidades raciais, mas, também por apresentarem uma trajetória histórica bastante paradoxal, achamos interessante tomar como estudo comparativo a noção popular e científica utilizada pelas sociedades brasileira e congolesa' ${ }^{1}$, a respeito da homossexualidade. Assim, consideramos importante iniciar nossas reflexões com a seguinte questão:

- Como as culturas populares brasileira e congolesa, no início do século XXI, posicionam-se em relação ao homossexualismo?

\section{ALGUNS ASPECTOS DA CULTURA POPULAR}

Evidentemente, estamos longe de podermos definir o objetivo da atividade sexual humana, e esse não é nosso principal interesse. Sobretudo porque esse campo de discussão tem se mostrado sempre estar envolto em interesses sociais, políticos e religiosos.

Sabemos que, historicamente, no Ocidente (que teve como alicerce cultural religioso o cristianismo), a atividade sexual humana esteve associada à orientação de procriação. Dizemos "esteve", porque se observa hoje um grande avanço em relação à tolerância e à aceitação da escolha do parceiro sexual, em vários países, como: Alemanha (principalmente após a Segunda Grande Guerra), França, Suíça, Inglaterra, e outros.

1. A República do Congo, que tem como capital Brazzaville, é um Estado da África Equatorial. Banhada pelo Atlântico, possui $342.000 \mathrm{~km}^{2}$ e 2,6 milhões de habitantes (estimativa de1997). Possui como língua oficial, o francês, e como religião, o animismo e o cristianismo. Mais de $58 \%$ da população é rural e a sociedade é composta de grande número de etnias. A exportação de petróleo representa $90 \%$ da receita do País. 
Contrariamente, em outros países, especialmente naqueles em "vias de desenvolvimento", como é o caso do Brasil e também do Congo, toda ação sexual que não visa a continuidade da espécie, no sentido de gerar uma nova vida humana é, ainda, considerada um comportamento "desviante". Acentuamos desviante por se tratar de um comportamento que, sob esse ponto de vista, distancia o homem de sua finalidade principal: aproximar-se da perfeição divina. $\mathrm{O}$ ato sexual, nesse sentido, é entendido como uma ação animal que visa simplesmente a "escravização do espírito humano" à matéria, ou seja, a manutenção da espécie.

Partindo desse princípio, será desviante todo comportamento sexual humano e, em especial, o homossexual, visto que o contato sexual dos corpos dos homossexuais, bem como a obtenção de prazer, serão infrutíferos, uma vez que não poderão reproduzir o ato da "criação".

Contudo, convém salientar, segundo esse mesmo princípio, que a conduta de parceiros de sexos diferentes, que fazem uso de meios contraceptivos, mostra-se tão infrutífera quanto aquela da relação entre parceiros do mesmo sexo. Assim, os contatos sexuais na relação heterossexual que não possibilitam o surgimento de uma nova vida, podem também ser considerados comportamentos "desviantes". Nesse caso, incluiríamos os casais estéreis, os de idade avançada, em que a mulher já passou pela fase do climatério, e outros. Se o exercício do "comportamento desviante" merece ser descrito, será difícil então encontrar um grupo que não se inclua nessa descrição. A concepção da função sexual se mostra, portanto, autoritária e distante da realidade vivida pelas sociedades atuais; somos levados, pois, a buscar outras respostas para essa questão.

Em uma outra concepção, podemos entender que a recusa à "idéia única de procriar", na relação sexual, seria própria da diferença entre o homem e o animal. O "fatalismo procriador do ato sexual" seria próprio dos animais e não, necessariamente, do homem. O homem, fazendo uso de sua subjetividade, repete $o$ ato da criação mediante suas descobertas científicas que poderiam aproximá-lo da onisciência divina. Isto é, por ser dotado de uma inteligência diferenciada, o homem tem como missão "recriar a criação" e ultrapassar tal estado de fatalidade a que os demais seres estariam "condenados".

Portanto, será "desviante", segundo essa perspectiva, optar pela não concepção de um novo ser, sobretudo, se essa opção for objeto de uma escolha consciente. Só as espécies animais inferiores à espécie humana, estariam autorizadas à não escolha, devido à forte incidência dos instintos sobre elas, em especial o da manutenção da espécie. O não-exercício dessa escolha pelo homem, leva-o a regredir a um estágio inferior de sua evolução. No entanto, com o advento dos métodos contraceptivos, $\mathrm{o}$ ato sexual e $\mathrm{o}$ ato procriador se tornaram independentes. Será que, a partir desse momento, teremos que começar a pensar quando podemos praticar o ato sexual com a finalidade de procriação e quando podemos praticá-lo pelo prazer do jogo sexual? 
Não acreditamos que as respostas às nossas questões venham desta reflexão. Ao homem lhe foi dada a oportunidade de escolha. Ser "humano" implica então em fazer uso de suas capacidades e possibilidades diversas. Acreditamos que seja compreensivo e correto, mediante a conjuntura psicológica e socioeconomica de cada sujeito, poder escolher e planejar o momento da procriação, mas, que esse exercício não infira na relação de prazer que, aliás, é inerente ao ato sexual humano. $\mathrm{O}$ que mais nos interessa no momento, seria então a criação de uma consciência social que visualizasse, com objetividade, o entendimento da vida sexual humana dentro de sua diversidade. Não seria conveniente nos fixarmos excessivamente nos conceitos religiosos que, mesmo sendo importantes, podem se mostrar não sincronizados com o tempo, mantendo a exclusão de uns e a ignorância de outros, ambos geradores de sofrimento.

Podemos, no entanto, decidir pela prática sexual como um modo de obtenção de prazer, resguardando completamente nossa dignidade e nossa "normalidade". Assim, se sujeitos do mesmo sexo ou de sexos diferentes decidem usufruir do prazer que o ato sexual poderá lhes proporcionar, esses não estariam cometendo nenhuma transgressão ou "desvio" de conduta.

\section{ALGUNS ASPECTOS PSICOPATOLÓGICOS DO HOMOSSEXUALISMO}

Referente ao questionamento anterior, faz-se necessário refletir, quando um comportamento sexual será desviante, a partir de uma abordagem psicopatológica.

Criada em fins do século XIX, pela psiquiatria e re-elaborada pela psicanálise, o termo perversão designava "uma conduta sexual desviante na qual o parceiro não é considerado como um sujeito, mas, simplesmente como um objeto necessário à satisfação sexual e por quem se sente uma forte hostilidade" (Bonnet, 1993, p. 7).

A partir do quadro da nosografia corrente (descrição metódica das doenças), podemos precisar que, de maneira geral, as perversões, "designam comportamentos e sintomas que se manifestam no sujeito de forma diversa, de freqüência episódica ou durável em função de uma organização psíquica estável e particular" (Bonnet, p. 8-13). As perversões podem ser caracterizadas da seguinte forma:

1. São eminentemente pessoais, correspondendo a um código inconsciente visando o prazer auto-erótico onde o parceiro não é levado em conta; portanto, toda perversão é solitária e se constitui num mistério mesmo para aquele que a pratica;

2. Tendem a se tornarem exclusivas, eliminando toda outra forma de prazer; 
3. Tendem a se tornarem em certos casos, repetitivas, estereotipadas e cristalizadas, destituídas de qualquer significação aparente, impondo-se sobre o sujeito de maneira cada vez mais irracional;

4. São normalmente portadoras de forma consciente ou inconsciente de um ódio ou uma hostilidade violentos.

A perversão, ou a designação do que seja um comportamento perverso, é assim elaborada sempre em relação ao sistema sócio-cultural. Portanto, a designação desse termo permanece flexível, visto que tende a evoluir à medida que a sociedade muda seus hábitos e os grupos concernentes que dela fazem parte ganham espaço e respeito para suas ações.

Dentre os inúmeros comportamentos perversos, o homossexualismo sempre foi associado às "perversões de objeto". A psicanálise considera tradicionalmente como "perversões de objeto" toda forma de relacionamento sexual onde o parceiro submisso se coloca no lugar do primeiro parceiro proibido, normalmente a mãe (Bonnet, p. 33-34). Tais perversões são a zoofilia e a necrofilia, de um lado; e a pedofilia e o homossexualismo, de outro. Porém, precisamos estar atentos ao fato de que, no conceito popular, o sujeito homossexual está associado ao pederasta, o que é um grande erro. De fato, para Bonnet (p. 101-102), o comportamento homossexual só poderia ser considerado perverso dentro de situações particulares, tais como:

1. Quando o ato homossexual é associado a outras atitudes especificamente perversas (sadismo, masoquismo, voyeurismo, etc.), ou quando faz uso de outras modalidades (cenários específicos, rituais, fetiches);

2. Quando o homossexual sente um desejo irresistivel de dirigir a excitação sobre o outro sexo;

3. Quando o ato homossexual conduz à exclusão de toda outra forma de sexualidade, fixando-se na estereotipia e na sistematização.

No entanto, não se deve esquecer que toda essa conduta dita perversa, pode estar presente, da mesma forma, nas relações heterossexuais. Desse modo, poderíamos, então, excluir o conceito de perversão, que não estaria necessariamente, ligado a toda conduta homossexual ou à conduta homossexual propriamente dita.

Vale lembrar um segundo erro, freqüentemente encontrado na concepção popular, o qual salienta que a pedofilia e o homossexualismo são fenômenos da mesma ordem. O pedófilo é alguém que obtém prazer, preferencialmente nas relações mantidas com crianças e adolescentes. Nesse caso, a presença de um fantasma condiciona a vida psíquica do sujeito, ligando-o à figura de uma criança ou "menor", fato que torna uma preferência sexual numa necessidade e, posteriormente, numa exclusividade, onde o sujeito recusa sistematicamente outras formas de relação sexual e de obtenção de prazer. 
Um terceiro erro freqüente da concepção popular é a associação feita entre homossexualismo, transexualismo e travestismo. Nesses dois últimos casos, o homossexual masculino é sempre confundido com alguém que nega seu sexo biológico e gostaria de obter uma genitália feminina (transexualismo), que se veste de mulher e que se identifica com a "imagem" de ser mulher (travestismo). Lembramos que os mesmos termos e conceitos (transexualismo e travestismo) podem estar presentes no homossexualismo feminino. Evidentemente, para o mundo científico, isso tudo não passa de um erro de interpretação e de uma grande falta de informação, característica das sociedades católicas. Fato que explica grande parte dos tabus e interdições existentes em países ocidentais ou que receberam influência ocidental, no que tange, é claro, à vida sexual humana.

Desprats-Péquignot (1992, p. 70) salienta que, segundo a perspectiva freudiana, sob o âmbito do inconsciente não existe nada que distinga o masculino do feminino, visto que essa distinção não é redutível ao sexo biológico, mas, ao tipo de identificação que o sujeito constrói em relação ao "falo"2. Essa tese pode ser confirmada pela relação que o sujeito transexual mantém com seu status biológico; o transexual não deve ser identificado nem como homossexual nem como travesti. A questão sexual para estes sujeitos ocupa um segundo plano, uma vez que tais sujeitos vivem um problema relativo à sua "identidade sexual". Para eles, o sexo biológico (pênis ou vagina) no qual se encontram prisioneiros constituem um erro da natureza. Em seus discursos, deixam transparecer um sentimento de que existe uma "alma de mulher", dentro de um corpo de homem, ou o contrário. Ainda segundo Desprats-Péquignot, existe aqui uma consciência do sexo anatômico, mas, não existe uma aceitação de que esse sexo anatômico (pênis ou vagina) bem como seu estado jurídico, não estaria em conformidade com o "verdadeiro sexo aprisionado". O travesti, por sua vez, não coloca necessariamente em questão seu sexo anatômico, nem sua identidade sexual (masculina ou feminina). Sob o plano individual, a prática travesti oculta diferentes modos de organização do desejo e de obtenção do prazer sexual que estão diretamente relacionados com a questão da "castração" e do "falo". No entanto, é importante lembrar que, em um mesmo caso de homossexualismo, pode-se encontrar aqueles ou aquelas, que se vestem de mulher ou de homem (travestis) e que desejam submeter-se a uma cirurgia de conversão de sexo (transexuais).

Isso nos mostra que, nem sempre em todos os casos de homossexualismo, o sexo anatômico bem como a identidade sexual do indivíduo é, obrigatoriamente, colocada em questão. Entende-se que, no homossexualismo, o

2. Para Freud, o falo representa o caráter intrínseco da libido. Considera ainda que a libido é essencialmente masculina, mesmo quando se refere à criança do sexo feminino (Chemama, 1995, p. 234-235). 
sujeito não é necessariamente impulsionado ao desejo de possuir um sexo que não tem. $\mathrm{O}$ sujeito, não está sempre, em todos os casos, levado à uma tentativa de reparação da "castração" vivida pela mãe (aquela que - no imaginário infantil - enquanto mulher, perdeu seu "falo", como forma de punição por algo errado que cometeu), feita pelo travesti.

Segundo nossas observações, o sujeito homossexual não é uma forma particular de "ser" humano e, portanto, não deve ser considerado como um grupo particular em relação ao grupo masculino ou feminino. Para sermos ainda mais claros, os homossexuais não se tratam de um "terceiro sexo", mas, sim, de homens e mulheres que optaram e encontraram desejo e formas de satisfação do desejo sexual com parceiros do mesmo sexo. E que, infelizmente, ainda por "forças de circunstâncias" ou de uma moral social intolerante, estão situados em algumas sociedades ocidentais, dentro de uma perspectiva relacional particular.

\section{REFLEXÕES SOBRE O HOMOSSEXUALISMO NO BRASIL E NO CONGO}

Normalmente, alguns indivíduos ou grupos sociais, em função de uma percepção unilateral dos fenômenos que giram em torno de sua realidade, tendem a guardar sua "tendência etnocêntrica"”. Essa tendência é um fator que impede que nos situemos criticamente diante de nossos próprios posicionamentos. Assim, consequientemente desconhecemos o que vivem outros contextos sócio-culturais e, com isso, deixamos de aprender com os erros já cometidos por outros, ao longo de suas história.

Consideramos importante, pois, investigar de que maneira o homossexualismo é interpretado e acolhido em outro contexto sócio-cultural diferente do da sociedade brasileira. Em função da vastidão de informações que um estudo amplo poderia nos conduzir, limitar-nos-emos a refletir sobre alguns aspectos da questão do homossexualismo no Brasil e no Congo.

\section{HOMOSSEXUALISMO NO BRASIL}

No Brasil, quando se faz referência à questão do homossexualismo, somos rapidamente levados a pensar em dois aspectos que melhor representam esta sociedade. $\mathrm{O}$ primeiro deles é, evidentemente, $\mathrm{o}$ aspecto religioso.

3. Tendência do pensamento a considerar as categorias, normas e valores da própria sociedade ou cultura como parâmetro aplicável a todas as demais. 
Estamos aqui diante de uma das sociedades de maior população católica do mundo ocidental, na qual se consideram na prática os valores da Igreja Católica. Esse é um fator importante que diferencia o Brasil de outros países católicos do ocidente. Na França e na Espanha, por exemplo, há um elevado número de católicos embora exista uma orientação política pela qual o Estado se mostra essencialmente leigo. Assim a reduzida importância da participação do Clero nas decisões políticas do país, contribui para que a vida privada dos indivíduos seja pouco condicionada pelas orientações do Vaticano. O segundo aspecto seria o sociocultural, que caracteriza essa sociedade de forma ainda melhor. Fortemente impregnada de valores "machistas" e de uma insustentável desigualdade social, crianças e mulheres sofrem barbaridades, por ainda não terem conquistado o reconhecimento e o respeito merecidos, como cidadãos de direitos e deveres iguais aos do homem.

Assim, a visão cristã relativa à sexualidade humana e às práticas machistas são fatores decisivos no modo como os brasileiros se posicionam em relação ao homossexualismo. O discurso católico, numa tentativa de assumir uma postura mais tolerante, não condena o homossexual, mas, incentiva a sublimação do desejo sexual desaconselhando sua realização entre parceiros do mesmo sexo $0^{4}$. De maneira consciente ou inconsciente, pelo fato da relação homossexual ser infrutífera (no tocante à procriação), entende-se que essa representaria simplesmente um ato de bestialidade. Aos "olhos" do julgamento popular, o homossexual é considerado então, um "fora da lei", desviante, marginal, enfim, perverso. No entanto, o mesmo fato pode ser observado no desejo feminino de poder usufruir de sua sexualidade. Fato facilmente identificável, através da história da Igreja Católica no ocidente; para a mulher, foi negada qualquer possibilidade de viver sua sexualidade de forma autêntica, pois, a "figura" da mulher continua ofuscada, apagada e sem significado, em relação à sexualidade; "mulher não tem que querer sentir prazer sexual".

Tomando como referência ambas as perspectivas, poderíamos dizer que a moral cristã tem atuado como um veículo de elevação do sofrimento desses sujeitos, incentivando o aumento da incoerência entre o poder "ser" e "viver" o que se "ê". Se, aparentemente, o discurso cristão se mostra aberto à modernidade e tolerante a tais sujeitos, vemos que, em função de nossa trajetória histórica, esse se encontra tão retrógrado quanto o era na Idade Média.

No quotidiano da sociedade brasileira, vemos como os sujeitos homossexuais são vítimas de um processo de exclusão em nome do cristianismo.

4. "A própria renúncia ao exercício da sexualidade não tem por que ser neurotizante nem problemática. Como o celibato imposto pelas circunstâncias, sempre há um lugar para a sublimação, que é difícil de conseguir, mas não impossível." Azpitarte (1984, p. 368-368). 
Essa exclusão que, teoricamente limita-se "a brincadeiras e piadas entre amigos", na prática, chega a comprometer o futuro profissional dos indivíduos envolvidos. Exemplo disso: o relato de um adolescente de 14 anos (Trevisan, 1999) que, ao revelar seu "amor" por um colega de escola, foi radicalmente excluído, tanto pelos colegas quanto por professores e pela própria direção da escola. O diretor do colégio Agostiniano Mendel, situado na zona leste de São Paulo, respondeu à denúncia de discriminação dizendo que homossexualismo é "anormalidade". De fato, tal postura popular parece responder à orientação cristã que tende a incentivar movimentos de discriminação. Jovens que deveriam ser preparados para o exercício da cidadania são formados para o desrespeito aos direitos humanos. Na mesma escola, os adolescentes chegaram a criar o MMB - movimento cujo lema é "Matem Muitas Bichas".

Tais práticas se situam à base de inúmeros incidentes, aumentando ainda mais o número de vítimas de discriminação. Não raro, incentivados por uma concepção machista das relações sociais, alguns grupos de esportistas discriminam e revelam uma verdadeira aversão aos homossexuais (Luz, 1999). Casos mais extremos de agressão verbal, espancamentos e mortes, ilustram as páginas policiais de nossos jornais quotidianos.

Para o conceito popular, além de contradizer as orientações cristãs, a prática homossexual agride a representação "machista" que o grupo masculino tem em relação a seu próprio sexo biológico. De fato, o homem brasileiro considera que sua masculinidade lhe é atribuída basicamente pela posse de um pênis. Indivíduos que apresentam algum distúrbio sexual, como por exemplo, o da ereção, antes de investigarem os aspectos psicológicos e relacionais que poderiam estar interagindo na causa da dificuldade, esses, se lançam numa pesquisa médica para diagnosticar o que há de errado com seu "membro viril".

Ora, se o fato de ter um pênis, para muitos homens, é a garantia da afirmação de sua masculinidade frente ao "outro", sua própria masculinidade é então colocada em questão, logo após a constatação de um diagnóstico de impotência sexual, por exemplo. Assim, diante da ameaça sentida, o "macho" se lança num processo de destruição do "antimacho".

As práticas discriminatórias contra o homossexualismo se mostraram tão alarmantes que, em 1999, levaram o deputado Nilmário Miranda (PTMG), presidente da Comissão de Direitos Humanos da Câmara, a apresentar um projeto que altera a Lei $\mathrm{n}^{2} 7.716$, redefinindo os crimes de preconceitos antes relacionados apenas àqueles de raça, cor, etnia, religião e nacionalidade, e omitia a questão do homossexualismo. Dentro desta mesma perspectiva, em 12/05/2000, o prefeito da cidade de Juiz de Fora/MG, Tarcísio Delgado, assinou o projeto de Lei 09791/2000 (ver anexo) que dispõe sobre a ação do Município no combate às práticas discriminatórias em sua cidade, a respeito da orientação sexual e da liberdade da conduta homossexual. Evidentemente, a criação de leis não garante uma real mudança social. Para 
que tal mudança ocorra, será preciso desenvolver um trabalho de conscientização que envolva todas as forças atuantes no País, responsáveis por processos educativos; ou seja, escola, igreja, associações, e outros.

Em síntese, podemos dizer que, na cultura brasileira, a questão homossexual caminha a passo duplo e transversal. De um lado, existem movimentos e incrementos de leis que buscam despertar na consciência social o respeito à dignidade humana, independentemente das escolhas sexuais. De outro lado, vemos também movimentos e posições teóricas que tentam manter intacta a concepção de que a prática sexual só é possível quando os indivíduos envolvidos são de sexos diferentes. Observa-se, no entanto, que de fato, existe uma tentativa de modernizar e colocar as práticas sociais brasileiras, no mesmo ritmo e avanços já presentes em outros países; além do respeito à livre escolha do parceiro sexual, a legislação dá direitos iguais aos casais heterossexuais e homossexuais, como ocorre na Inglaterra, Suíça, Holanda e outros. Porém, constata-se que os esforços políticos no Brasil, relacionados à questão, ainda estão em dissonância com a consciência social de sua população.

Provavelmente, a influência da moral cristã, presente na sociedade brasileira desde sua fundação é, em grande parte, responsável por essa intolerância. Outros países que também receberam a mesma influência, como é o caso do Congo, guardam uma postura ainda mais radical e discriminatória em relação à questão.

\section{HOMOSSEXUALISMO, CULTURA E DOENÇA MENTAL NO CONGO}

No caso do Congo, veremos que a cultura cristã, ainda fortemente difundida na atualidade, contribuiu para reforçar posições arcaicas e valores sociais tribais que excluem, radicalmente, todos aqueles que se mostram "divergentes".

Contrariamente às sociedades consideradas industrializadas, a questão do homossexualismo no Congo é tratada a partir de uma leitura social que postula sobre um modelo único de união sexual. Tal modelo está, essencialmente, fundamentado nas bases de uma ideologia religiosa e de antigos costumes que servem como referencial cultural para a orientação de atitudes e de comportamentos dos membros da "comunidade-clã".

Segundo a crença religiosa dessa população em particular, $o$ ato sexual não pode se realizar entre dois indivíduos de mesmo sexo. Tal postura é fundamentada pela leitura bíblica, de que Deus criou Adão e Eva, e que esses experimentaram do fruto da árvore do conhecimento do Bem e do Mal. Releva-se ainda a questão da punição iniciada em Adão e Eva, depois estendida para a humanidade, por esses primeiros terem comido do fruto da árvore proibida. Embora se acentue a punição que Deus infligiu a Adão e 
Eva, a idéia que prevalece é a de que, por excelência, o homem deve se colocar ao lado da mulher, e que essa, faz parte do homem. Esta concepção deixa claro e irrefutável o papel social do homem e da mulher, o qual veremos a seguir, onde a sexualidade ainda faz parte da imagem total do grupo.

No Congo, o reconhecimento do papel feminino passa pela capacidade de procriar, de dar a vida; portanto, função materna, que tem como significado fundamental o de detentora da vida - aquela que coloca o "ser" no mundo e é a guardiã da vida. Tal ideologia é considerada tão importante que o papel do homem é minimizado no processo de fecundação: o produto do macho (o esperma) serve apenas para ajudar no crescimento de um "ovo" surgido unicamente na mulher. Resultado: o produto do macho é considerado tão perigoso para a vida que o homem não pode ter relações sexuais com sua mulher, se ela estiver grávida, e ele deve ainda esperar até o final do aleitamento.

Nesse contexto, a expressão da feminilidade não se faz mediante a exibição do corpo feminino ou de tarefas específicas (tipo domésticas e outras), mas, na "concepção" da vida. O reconhecimento da mulher e, portanto, de sua feminilidade, faz-se graças à maternidade e em função desta coesão entre mulher e vida (onde a mulher garante a vida/sobrevivência do grupo social); a mulher como o "representante" da antimorte une a função sexual à vida e, assim, ganha sentido e forma.

Dentro dessa perspectiva, o ato sexual praticado entre pessoas de mesmo sexo é considerado como algo "fora da norma"; portanto, ilegal e passível de qualquer forma de rejeição e exclusão. Diz-se que essa prática representa "tocar algo impuro" e é ainda vista como um tabu que caminha contra os modelos de "ideal" para o grupo. É interessante lembrar que a noção de tabu, para Wund (1965), designa "toda proibição imposta pelos usos e costumes ou formulada dentro das leis, de tocar um objeto, de se apossar ou de se servir de certas práticas proibidas". Na leitura mais antiga dessa sociedade, está indicado que as proibições mais primitivas e importantes são representadas pelas leis fundamentais do totemismo que estabelecem: "não devemos matar um animal totêmico" e "devemos evitar relações sexuais com indivíduos cujo sexo pertence ao mesmo totem". É preciso considerar que dentro de tais culturas, tidas como "primitivas", considerava-se que cada indivíduo tinha um Deus protetor. Tal Deus vivia no mundo sob a forma de um animal e portanto se fazia necessário proteger o animal que representava o deus que os protegia. Assim, por exemplo, se meu Deus protetor fosse o porco, não deveria matá-lo, pois ao contrário, estaria lançando sobre mim mesmo uma maldição. No intuito de reduzir o número de incestos bem como de facilitar as trocas entre as famílias, as sociedades mais primitivas consideravam que uma mulher não deveria jamais se relacionar sexualmente com seus filhos, visto que possuíam o mesmo totem (Freud, 1923). Neste caso, considerava-se que o totem da mãe era naturalmente transmitido para seus filhos, o que não ocorria com o pai. Porém por serem os irmãos pertencentes a um mesmo totem, as relações sexuais entre eles seriam 
consideradas uma ofensa aos deuses. Para garantir a sobrevivência dos grupos e o poder do patriarca expresso pelo seu número de descendentes, a união sexual entre o homem e a mulher era fundamental. Para essa população, a homossexualidade está, sem dúvida, "enraizada" no inconsciente coletivo como a representação de uma prática sexual já proscrita; portanto, a lei que proíbe tal prática, é aquela que deve apenas ser obedecida.

Mas, diante da realidade, tal autoritarismo não é completamente eficaz. Apesar da força restritiva dessa sociedade, alguns indivíduos tentam ultrapassar os limites das proibições. Podemos supor que esses adotam uma atitude ambivalente em relação às proibições. Segundo Wund (1965), o "inconsciente poderá enfrentar inconscientemente essas proibições, mas, ele teme fazê-lo e teme porque, apesar de tudo, gostaria de fazê-lo". Esta atitude ambígua "do fazer e do não fazer" parece-nos que depende, intimamente, do status que ocupa o grupo na sociedade congolesa. Compartilhando com a teoria de Fotso Djemo (1982), isso gera uma "anulação do indivíduo diante do grupo e de suas exigências pessoais como também cria a total dependência do sujeito em relação a seu meio ambiente".

Numa perspectiva psicopatológica, podemos supor que, nesse contexto em particular, existe algo que seria da ordem do "inacabado" do "eu individual", o que conduz à desorganização e a um estado de dependência até mesmo patológico, não somente diante das condições do meio como também diante das pulsões. A noção de vontade própria passa a não existir diante da autoridade da comunidade-clã. O indivíduo não realiza sua "individuação"s a não ser que negue sua total participação no grupo; o que acontece normalmente por uma fuga ou abandono do clã. A unidade pessoal passa, então, a ser constituída pelos desejos e necessidades do grupo, e não pelos desejos e necessidades individuais. Aqui, o sujeito é inteiramente dependente da autoridade ancestral e religiosa, ambas guardiãs da memória coletiva. Isso ocorre, porque é essa autoridade que vela pelo respeito às leis sociais.

Desse modo, a posição do grupo familiar é decisiva na escolha do parceiro sexual. Normalmente, essa tarefa é dada aos pais e à família, os quais escolhem a esposa ou esposo de seus membros. Efetivamente, a família enquanto "objeto psíquico" pertence a um outro registro imaginário, diferente daquele do registro individual. O sujeito "é o que é" em função do grupo, pois, a representação de "individualidade" não tem nenhum significado.

Em psicanálise, o estudo deste objeto inconsciente, criado e investido pelo grupo é sustentado por três noções:

1) O fantasma do corpo familiar - prolongamento narcíseo do corpo de seus membros, análogo ao corpo maternal que o bebê imagina ser como o prolongamento de seu próprio corpo, Caillot e Dechef (1989);

5. Ato ou efeito de individuar(-se). Segundo a filosofia escolástica, seria a realização da idéia geral em cada indivíduo singular. 
2) A noção do "eu familiar", definida como uma formação narcísea sustentando a identidade familiar e o sentimento de pertencer ao grupo, assegurando apenas uma separação entre "o de dentro e o de fora", Eiguer (1987);

3) Um aparelho para pensar comum, chamado de "aparelho psíquico familiar" (Ruffiot, 1981) e que tende como "aparelho psíquico grupal" descrito por Anzieu (1975) à unificação regressiva e fusional dos psiquismos individuais de seus membros.

Dessa forma, o inconsciente do grupo, suas formações e sua sobrevivência repousam sobre um fantasma de auto-interligação, e a representação de um corpo comum e imortal está vinculada aos conteúdos indiferenciados e unificados do grupo. Assim, para um congolês reconhecer-se a si mesmo como indivíduo, possuindo existência própria, estaria, ao mesmo tempo, admitindo a vulnerabilidade $\mathrm{e}$ a fragilidade do grupo familiar.

$\mathrm{Na}$ etapa seguinte, os conteúdos do corpo familiar se diferenciam em "bons objetos", que devem ser conservados intactos e em "maus objetos" que devem ser rejeitados, pois, esses últimos ameaçam a integridade dos primeiros (Charazac, 1998). Esse corpo familiar, autêntico e unificado, nega ter necessidade de tudo que se relaciona com o exterior e revela suas origens em seus ancestrais únicos e poderosos. Em contrapartida, o grupo poderá também se confrontar com situações de abandono por seus ancestrais, possuindo assim um corpo vazio de seus "bons objetos".

A união das diferenças de sexos marca, nesse momento, um passo importante e complementar na imagem desse corpo familiar unificado da sociedade congolesa. Na "imaginação" de suas origens, a representação de um corpo comum é admitida através da existência de membros de sexos diferentes, onde circula o fantasma de sedução da cena primitiva ${ }^{6}$, e supõe-se que o grupo aceita ser originado da união de uma homem e de uma mulher. Como resultado esperado, a união de um homem com um homem ou de uma mulher com uma mulher cria, obrigatoriamente, uma crise familiar que tornar-se-á evidente na ativação de dois fantasmas: o do desaparecimento do sentimento de coletividade e o da regressão simbiótica.

$\mathrm{Na}$ clínica, por exemplo, o primeiro fantasma representa a vertente negativa de um movimento regressivo e narcíseo de idealização do grupo, manifestando-se pelo desejo de se formar uma família cujo poder de seus bens materiais (dinheiro, roupas, propriedades) protegeria-os de toda ameaça de desmembramento. O segundo fantasma traduz-se na imagem ideal de

6. Cena primitiva ou, também denominada cena original, refere-se à percepção imaginária ou real pela qual o sujeito presencia o coito de seus pais. Tal cena se revela importante devido ao trauma sofrido pela criança, que se transforma em um ponto de convergência das representaçōes inconscientes do sujeito. 
uma família simbiótica, onde o que é bom para um é bom para todos, e onde não pode haver algo que seja bom apenas para um e mau para os outros.

Em algumas sociedades que ainda guardam intactos certos conceitos culturais, vistos como primitivos, como é o caso do Congo, a simbiose familiar é percebida através de todas as formas de associação entre as espécies, desde o momento que ambos os sexos passam a tirar proveito até o parasitismo que beneficia um e deixa de nutrir o outro. No fantasma simbiótico familiar dessa sociedade, cada um vive reciprocamente como tendo necessidade vital do outro. Uma separação não representaria apenas "deixar de viver", mas, também provocar a destruição de todo o grupo.

Os casos citados abaixo ilustrarão, adequadamente, o que acabamos de descrever e mostram com clareza como o congolês é inteiramente submisso à autoridade do grupo, aos valores, crenças e símbolos que o caracteriza.

Na vida quotidiana dessa população, como era de se esperar, os homossexuais não podem e nem devem revelar sua escolha diferenciada, pois, as represálias são radicais e severas. Se, em países desenvolvidos, esses sujeitos podem se organizar em associações, fazer manifestações para fazer valer seus direitos, no Congo, tudo isso continua ainda como algo impossível. No inconsciente coletivo dos congoleses, um homossexual é, antes de tudo, um excluído da sociedade. Nenhum pai aceita que seu filho seja homossexual e a livre escolha de uma determinada prática sexual ou de um parceiro não existe.

Para ilustrar tal contexto, citaremos dois fragmentos de casos:

- O primeiro ocorreu em 1996, em Pointe-Noire (uma das grandes capitais do Congo). Um adolescente de 18 anos tinha confessado sua homossexualidade para seus pais. Seu pai, após essa confissão, ficou irado. Rapidamente, pegou uma faca e apunhalou seu filho, que morreu alguns minutos depois. Nenhum processo judiciário foi movido contra o pai assassino, além dos parentes se mostrarem favoráveis à atitude tomada por esse pai.

- O segundo caso é também relativo a um homem, de 29 anos. Esse revelou sua homossexualidade quando tomou conhecimento da sua condição de portador do vírus HIV. Após viver alguns anos ao lado de sua esposa, havia passado a ter práticas homossexuais, admitindo que o homossexualismo era, para ele, uma forma de prostituição que lhe permitia obter dinheiro para atender às necessidades financeiras de seus pais e de sua família. Era o filho mais velho e não havia conseguido um emprego até àquela idade. Por essa razão, não via nenhuma outra saída para seu futuro. Apesar de ter feito sua confissão com o objetivo de preservar a unidade de sua família, foi abandonado à sua própria sorte no hospital, até à morte. $\mathrm{O}$ enterro foi organizado pelo hospital; não, pela família.

A necessidade da prática homossexual com vistas a ajudar os pais, relatada nesse último caso, leva-nos a questionar o lugar do filho no meio 
familiar congolês. Estudos realizados na África sobre tal assunto atestam que o filho, membro de uma família africana, deve sempre recompensar os pais, por terem lhe dado a vida. Caso contrário, estará exposto aos riscos da maldição e do feitiço. Preservar as boas relações na família é também respeitar a ordem hierárquica estabelecida pela autoridade ancestral. Isto significa considerar necessariamente, o pai como o Deus na "terra". Um pai é, antes de tudo, aquele que conquistou as terras, aquele em torno do qual se formou e se estruturou a comunidade, o gerente e o guardião do patrimônio coletivo, aquele por quem e em torno do qual se distribuem e se redistribuem os papéis e as funções, o fundador da cidade e da comunidade. Porém, apesar do fato de nesse segundo caso, o filho se prostituir no intuito de garantir a manutenção da sua família, bem como de seus pais, ele passou a ser considerado um objeto tabu à partir da revelação de ter assumido o papel homossexual.

De forma geral, grande parte das doenças sofridas pelo sujeito Congolês, e em particular as doenças psíquicas, é avaliada como o resultado do não cumprimento, pelo filho, dos deveres para com aqueles que lhe deram a vida e participaram de sua educação. Embora o caso seguinte não se trate de um indivíduo homossexual, consideramos importante citá-lo para que tenhamos consciência da importância dada pela comunidade ao cumprimento dos deveres do filho em relação aos pais e aos parentes mais velhos.

- Um agente da alfândega, de 35 anos, foi hospitalizado no serviço de psiquiatria de Brazzaville. O diagnóstico médico confirmou a presença de um surto delirante agudo, seguido de uma crise de impaludismo. Apesar do diagnóstico ter sido confirmado pelos exames biológicos efetuados, tanto o paciente como sua família estavam persuadidos de que o doente não tinha cumprido com seu dever de obediência e ajuda a seus pais e, no entanto estava amaldiçoado. A doença seria então uma conseqüência de uma desobediência.

Constata-se, através desse último caso, que não só o homossexual, mas também outros indivíduos acometidos por doenças físicas e mentais, podem ser vítimas de atitudes de desprezo e castigos, até a completa exclusão do seio da sociedade. No caso em questão, apesar do sujeito ter cumprido aparentemente com seus deveres em relação à sua família, e portanto, ter pago a dívida natural em relação aos seus pais, ele não deixou de ser abandonado. Tal abandono é decorrente do fato de que sua doença foi considerada um castigo por um mal cometido. Um mal que é interpretado como o não cumprimento de um dever em relação aos pais, o qual não foi identificado antes que a maldição pudesse ser retirada. Esse cenário atual se aproxima das práticas psiquiátricas em voga no século XIX, revelando um grande atraso na concepção científica de doença mental desse País, em relação às sociedades ocidentais industrializadas. 
A maior parte dos estudos conduzidos no campo da psiquiatria na África, atesta que a doença mental, no Congo e no continente africano em geral, considera a interferência de forças exteriores ao indivíduo e a intervenção maléfica, nos distúrbios mentais e orgânicos.

É interessante ressaltar, nesse ponto, que é apenas através da manifestação de uma doença mental que o indivíduo é capaz de adquirir o verdadeiro status de sua individualidade; fato que o possibilita contactar com as forças do universo. A doença mental também permite, ao mesmo tempo, que o indivíduo se integre com as forças da natureza. Esta concepção de indivíduo na sua relação com o universo permite-lhe esquivar-se de experiências humilhantes e angustiantes de culpa, projetando para o exterior e atribuindo aos seres malfeitores a origem de seus males.

Dessa forma, a origem do distúrbio mental é dada às forças do natural e do sobrenatural. Essa localização permite apreender um momento essencial de existência do sujeito, onde se entrelaçam de modo dialético as relações entre o homem e o mundo que o cerca.

Mais uma vez, voltaremos a ressaltar o importante papel do grupo nesta sociedade. A eficácia das técnicas tradicionais (primitivas) de cura, dependerão do consenso coletivo que considera a doença como uma "ferida" ocasionada pela invasão de um agente patogênico e vê no poder do "Nganga" e na coesão do grupo uma forma de escapar do caos. O papel do curandeiro é de restabelecer a ordem no grupo, revelando o malfeitor, ou seja, relatando quem é a pessoa maligna, responsável pela desordem.

Para desmascarar o feitiço ou o feiticeiro, o Nganga utiliza a linguagem cultural estabelecida numa comunhão entre ele e seus "consultantes"". Por detrás dessa linguagem, escondem-se referenciais de ordem social e pessoal, tais como: os problemas relativos ao não respeito à hierarquia, mais precisamente; à não submissão aos direitos de primogenitura (direito total do patriarca sobre os membros do grupo) e à recusa em obedecer às leis ancestrais. É, então, a partir do conhecimento da linguagem cultural e de seu manuseio, que os Nganga definem os axos etiológicos existentes e administram os tratamentos. Esses procuram sempre encontrar uma congruência entre a suposta causa da doença e a prescrição proposta, que pode ir desde a prescrição de plantas ao exorcismo, passando sempre pelo discurso familiar.

Corin e Bibeau (1975) distinguiram dois tipos de causas, às quais os terapeutas tradicionais se servem com grande freqüência: a causa-inicial e a causa-agente.

A primeira delas, causa-inicial, trata-se de todo um sistema etiológico; que coloca em evidência as ações causais da pessoa doente ou de alguém de

7. Termo genérico utilizado na língua Kongo, que significa especialista ou curandeiro.

8. Os consultantes são os indivíduos que procuram o Nganga com vistas a obtenção da cura, isto é, os pacientes ou clientes que normalmente se apresentam acompanhados por seus familiares. 
seu ambiente familiar. Já a Segunda, causa-agente, está presente nos vínculos ideológicos e em função de sua dependência à causa inicial. Ela considera a realidade de certas atividades metafísicas que se conciliam com os axos etiológicos. A determinação desses axos é um dos momentos importantes para o terapeuta tradicional, sem o qual sua função de estabelecer a ordem social estaria fadada ao fracasso. Uma função que tem seu reconhecimento compartilhado pelo grupo na sua totalidade, mesmo por aqueles cuja formação está, à priori, distante das crenças tradicionais. Essa forte adesão a crenças e aos terapeutas tradicionais pode ser considerada, como nos escreve Villaseñor (1977), como "uma forma de resistência cultural" contra todas as formas de importações ocidentais.

Desta forma, consultar o terapeuta tradicional (mesmo tendo deixado o meio familiar) significa aderir ao cenário cultural e solicitar o restabelecimento das boas relações no meio familiar. Os ritos que acompanham os terapeutas tradicionais visam levar ao conhecimento de todos as causas iniciais da doença mental e a descobrir, com precisão, o problema de uma pessoa ou de um grupo; problema esse que é o desencadeador da causaagente. É, freqüentemente, de natureza relacional, não é claramente desvendado pelo terapeuta tradicional, e é apresentado de modo totalmente enigmático, garantindo assim sua etiologia metafísica. Contudo, seu discurso é sempre bem recebido pelo grupo, pois, esse último, antes da consulta, já tem a convicção de que o problema não é originário do meio familiar e, sim, de forças sobrenaturais. O terapeuta tradicional agirá, então, sobre as causas sociais da doença e sobre a realidade metafísica que fora abalada pela ação do homem. Dessa forma, o tratamento administrado será um tratamento social visando restabelecer os laços sociais no meio grupal e resguardar as boas relações com os antepassados. Normalmente, dois tipos de tratamento caracterizam o dispositivo terapêutico tradicional:

- A fitoterapia (tratamento à base de plantas) e a espiritoterapia (terapia espiritual). Estas duas terapias são praticadas sempre durante uma grande reunião familiar chamada "palabre familiale" (resenha familiar). Participam dessa reunião todos os membros da família e, em algumas circunstâncias, o terapeuta tradicional, que tem por papel atenuar as tensões e, sobretudo, obrigar a pessoa ou as pessoas culpadas a se confessarem e a se reconciliarem com a vítima. Quando a reunião é bem-sucedida, o doente deverá reencontrar sua saúde, depois de algumas horas. Caso contrário, duas explicações são apresentadas:

- A primeira explicação fala do malfeitor que não aceita libertar o doente, fingindo pronunciar os votos de libertação sem "abrir seu coração". Nesse caso, fica a cargo do terapeuta tradicional, descobrir e ameaçar de morte o pressuposto culpado, até que ele confesse. Nesse momento, paradoxalmente a tudo que foi dito anteriormente, geralmente o culpado cede, pois, depois lhe é dada uma certa quantia de 
dinheiro que representa uma indenização pelo mal que o doente fez ao malfeitor no momento em que foi desobediente não respeitando a hierarquia. Assim o doente ou sua família, paga ao ofendido uma certa soma, como forma de se desculpar pela ofensa cometida. Nesse caso, o ofendido retira o feitiço, o ofensor se livra da doença e se restabelecem as ligações e o respeito no seio da família.

- A segunda explicação caminha no sentido de uma cumplicidade entre o terapeuta tradicional e o malfeitor. Isso ocorre quando a doença persiste (apesar dos diferentes recursos utilizados pelo terapeuta tradicional e pelos médicos) ou quando o pressuposto suspeito se recusa a fazer parte da reunião; ou ainda, nos piores casos, quando o doente morre, a família é que assume a responsabilidade do "acerto de contas". Normalmente, os mais jovens "entram em ação", sobretudo quando o culpado se trata de um deles. Esses jovens procuram o culpado, que é queimado em seguida numa grande fogueira de pneus, na presença de todo o grupo. Para se identificar o culpado, os jovens procuram verificar se houve alguém da família do falecido que de alguma forma tinha motivos para desejar a sua morte. Normalmente fazem parte dos suspeitos, os avós, os pais e os tios, isto é, pessoas que podem, uma vez tendo sido desrespeitadas, lançar uma maldição levando o jovem à morte. Dentre os parentes citados, procura-se verificar quem teria maior número de motivos para desejar a morte do jovem. Logo que o identificam o sentenciam e o executam. Tal prática, extra-oficial, é tão comum no Congo que a polícia não interfere, nem o Estado tem poderes para processar ou prender os que praticam a vingança pela perda de uma vítima de feitiço familiar.

Enfim, toda essa situação se traduz em dois fatores específicos para a compreensão da psicopatologia no Congo: inicialmente o sentimento de que um direito coletivo foi violado e, em seguida, o fato de que um superior tenha sido colocado em posição de inferioridade (trata-se do direito de primogenitura). Exemplos: um chefe de clã contra sua comunidade, um pai contra seu filho, o marido contra a esposa, a mãe contra seus filhos. Dessa forma, a conduta do terapeuta tradicional tem como objetivo principal mostrar que os status sociais foram invertidos e que é preciso restabelecer a ordem, "recolocando" cada membro no seu devido "lugar".

\section{CONCLUSÃo}

As diferenças existentes entre as teorias em voga e os aspectos culturais que envolvem a questão do homossexualismo entre nesses dois países, não nos autoriza a considerar que a ideologia ainda presente no Congo seja 
sem sentido. De fato, existe nesse último contexto, uma coerência entre a teoria e a prática, sendo possível entender, após toda essa reflexão, que no Congo o homossexualismo não pode ser considerado algo diferente de uma doença mental.

Assim, é importante estarmos atentos ao fato de que essa população considera, tanto na teoria quando na prática, que a doença mental reflete um desequilíbrio vivido no meio familiar e social. Uma concepção coerente que está longe de ser vista como arcaica. A percepção crescente de que os medicamentos que atuam sobre o psiquismo humano não são capazes de reduzir efetivamente o sofrimento humano, instiga-nos a buscar respostas não apenas no biológico e individual, mas, sobretudo no que se situa exterior ao próprio indivíduo. Estamos, pois, a cada dia, sendo convencidos de que a doença mental está intimamente ligada às diferentes questões vividas pelos indivíduos, no seio de cada sociedade.

Segundo nossas observações, no contexto africano em particular, o homossexualismo seria a pura representação da antivida, da infertilidade, numa sociedade onde toda a riqueza se concentra na questão da virilidade do macho diante da reprodução. Observa-se que, até os dias de hoje, nessa sociedade, não se manifesta nenhum interesse de "mudança social", visto que qualquer mudança poderia colocar em risco o poder patriarcal e, conseqüentemente, gerar uma possível dissolução da unidade grupal. Assim, fica claro que, quanto ao homossexualismo, no momento, essa questão não pode ser outra senão o alvo da intolerância e da inflexibilidade. Tolerar o homossexualismo, ou seja, aceitar a existência de relações infrutíferas, colocaria diretamente em questão o poder, bem como a imagem viril do pai, que é mantida pelo número de descendentes.

A figura da mulher, neste contexto, continua submissa ao jugo do marido ou do pai; de um lado, é reforçada pela ideologia religiosa, e de outro, pelos valores culturais que "fazem questão" de manter intacta a figura do pai. O patriarca que possui maior prole, conseqüentemente, será detentor de maior poder perante o grupo. Nesse lugar, seria inadmissível para um progenitor, aceitar a interrupção da continuidade de sua descendência. Seria inconcebível, que um de seus membros se recusasse a participar do processo de reprodução da vida, ou seja, de interromper a continuidade de seu clã. Aqui, o homossexualismo representa um grande risco para a estrutura sociocultural do grupo. Ele agride diretamente as orientações ancestrais e a autoridade do grupo, visto que o desejo individual está "entrelaçado" ao desejo do "outro". Numa sociedade onde o poder e a vontade do grupo se sobrepõem ao desejo individual, seria um contra-senso permitir que o desejo individual, no caso, a livre escolha de um parceiro sexual, fosse aceita.

Porém, no caso do Brasil, a questão não pode ser analisada dentro dessa mesma perspectiva. É preciso que busquemos estabelecer uma coerência entre nossas práticas e as teorias que as fundamentam. Nesse país, se tomarmos como ponto de referência a relação entre o sujeito e seu grupo, 
veremos que nossa sociedade é marcada pelo triunfo do individualismo sobre as relações grupais. A noção de valores ancestrais, bem como aquela de que "o filho deve ao pai o que esse lhe ofereceu", em muitos casos, deixou há muito tempo de existir.

$\mathrm{Se}$, na sociedade brasileira, a palavra de ordem é a autonomia e o individualismo, como não aceitar a livre escolha de um indivíduo, no tocante à sua vida sexual? Se não pudermos, cientificamente, dar uma resposta à questão do homossexualismo e se talvez não existam respostas a serem dadas, entendemos que devemos ter uma prática profissional emergencial. Precisamos, desde nossa intervenção individual no consultório particular, até uma atuação orientadora e conscientizadora quando atuamos com grupos ou publicamos o resultado de nossas investigações, seguir a lógica da coerência.

Não há como "globalizar" (pelo menos por um longo tempo) nossa compreensão a respeito do comportamento homossexual. Indubitavelmente, tal prática ocupará sempre estatutos diferenciados em consonância com os grupos particulares. Estamos aqui diante de um fato que nos incita a perguntar: temos já competência para estabelecer regras que definem o normal e o patológico relativo à ação humana, uma vez que o sujeito e seu grupo se encontram ainda em evolução e que todo conhecimento sobre o social não é ainda definitivo? Parece-nos que tudo o que podemos tentar fazer é desenvolver nossa capacidade de aceitação do outro e de suas escolhas. Sem dúvida, aceitar as diferenças existentes na atualidade é um ato que pode promover o bem-estar nosso e da sociedade inteira, no futuro.

\section{REFERÊNCIAS BIBLIOGRÁFICAS}

1) AZPITARTE, E. Práxis Cristã, opção pela vida e pelo amor. São Paulo: Paulinas, 1984.

2) BONET, G. Les perversions sexuelles. Paris: PUF, 1993.

3) CHARAZAC, P. Psychothérapie du patient age et de as famille. Paris: Dunod, 1998.

4) CHEMAMA, R. Dictionnaire de la Psychanalyse. Paris: Larousse, 1995.

5) DESPRATS-PÉQUINOT, C. La psychopathologie de la vie sexuelle. Paris, P.U.F., 1992.

6) FREUD, S. (1913) Totem et Tabou. Paris: Payot, 1965, 37-40 p.

7) FREUD, S. (1924), Névrose, psychose et perversion. Paris: PUF, 1997.

8) FOTSO DJEMO, J.B. Le regard de l'autre: médecine traditionnelle Africaine. Paris: Silex, 1982.

9) GRESSOT, M. Les relations de transfert dans la maladie mentale et thérapies des cultures primitives. Paris: Evolution psychologique, 1955.

10) LUZ, S. "Sou gay e jogo como um homem". Revista Veja, p. 70-72, 31 de março de 1999. 
11) MOUKOUTA, C. Représentation de la maladie mentale et thérapies traditionnelles au Congo: réflexion à partir de l'étude d'itinéraires thérapeutiques. Thèse de doctorat en psychologie clinique et pathologique, Université de Picardie Jules Verne, 2000.

12) PEWZNER, E. Introduction à la psychopathologie de l'adulte. Paris: Armand Colin, 1995.

13) TREVISAN, C. O amor que ameaça. Revista Isto é, $\mathrm{n}^{0} 1569$, p. 128-129, 27 de outubro de 1999.

14) VILLASEÑOR, S.J. Vers une ethnopsychiatrie mexicaine: la médecine traditionnelle dans la communauté Nahua de Guerrero. Thèse de doctorat en Anthropologie sociale et ethnologie. Paris: EPHS, 1997. 


\section{ANEXO \\ [CMJF - Câmara Municipal de Juiz de Fora] [iS@L] $i \mathrm{~S} @ \mathrm{~L}$ \\ Sistema de Acompanhamento Legislativo}

\section{Norma: LEI 097912000 Data: 12/5/2000 Origem: Legislativo}

Ementa: Dispõe sobre a ação do Município no combate às práticas discriminatórias, em seu território, por orientação sexual.

\section{Indexação: DETERMINAÇÃO, AÇÃO, MUNICÍPIO, DISCRIMINA- ÇÃO, ORIENTAÇÃO, SEXO, HOMOSSEXUAL, SANÇÃO, MULTA, SUSPENSÃO, ALVARÁ}

\section{Catálogo: DIREITOS HUMANOS}

Lei $\mathrm{n}^{2} 9791$ - de 12 de maio de 2000.

Dispõe sobre a ação do Município no combate às práticas discriminatórias, em seu território, por orientação sexual.

A Câmara Municipal de Juiz de Fora aprova e eu sanciono a seguinte Lei:

Art. $1^{2}$ - Será punida, no Município de Juiz de Fora, nos termos do art. $1^{\circ}$, incisos II e III, art. $3^{\circ}$, inciso IV e art. $5^{\circ}$, incisos Xe XLI, da Constituição Federal e do art. 114 da Lei Orgânica Municipal, toda e qualquer manifestação atentatória ou discriminatória praticada contra qualquer cidadão homossexual (masculino ou feminino), bissexual ou transgênero.

Art. $2^{\varrho}-$ Consideram-se atos atentatórios e discriminatórios aos direitos individuais e coletivos dos cidadãos homossexuais, bissexuais e transgêneros, dentre outros:

I - submeter o cidadão homossexual, bissexual ou transgênero a qualquer tipo de ação violenta, constrangedora, intimidatória ou vexatória, de ordem moral, ética, filosófica ou psicológica;

II - submeter o cidadão homossexual, bissexual ou transgênero a qualquer tipo de ação violenta com o emprego de agressão física;

III - proibir o cidadão homossexual, bissexual ou transgênero de ingressar ou permanecer em qualquer ambiente ou estabelecimento público ou privado;

IV - praticar atendimento selecionado que não esteja devidamente determinado em Lei;

V - preterir, sobre-taxar ou impedir a hospedagem em hotéis, motéis, pensões ou similares;

VI - preterir, sobre-taxar ou impedir a locação, aquisição, arrendamento ou empréstimo de bens móveis ou imóveis de qualquer finalidade;

VII - praticar o empregador, ou o seu preposto, atos de demissão direta ou indireta em função da orientação sexual do empregado; 
VIII - Inibir ou proibir a admissão e o acesso profissional em qualquer estabelecimento público ou privado em função da orientação sexual do profissional.

IX - proibir a livre expressão e manifestação de afetividade do cidadão homossexual, bissexual ou transgênero, sendo estas expressões e manifestações permitidas aos demais cidadãos.

Art. $3^{2}$ - São passíveis de punição o cidadão, inclusive os detentores de função pública, civil ou militar, e toda e qualquer organização social ou empresa, sejam elas detentoras de personalidade física ou jurídica, com ou sem fins lucrativos, de caráter privado ou público, instaladas no município, que intentaram contra o que dispõe essa Lei.

Art. $4^{2}-$ A prática dos atos discriminatórios a que se refere esta Lei será apurada em processo administrativo, que terá início mediante:

I - reclamação do ofendido;

II - ato ou ofício de autoridade competente.

Art. $5^{\varrho}-\mathrm{O}$ cidadão homossexual, bissexual ou transgênero que for vítima dos atos discriminatórios mencionados no art. $1^{10}$ desta Lei poderá apresentar sua denúncia pessoalmente ou por carta, telegrama, telex, via internet ou fax ao órgão municipal competente e/ou Organizações Não-Governamentais que lutam pela cidadania e Direitos Humanos.

$\S 1^{2}-$ A denúncia deverá ser fundamentada através da descrição do fato ou ato discriminatório, seguido da identificação de quem fez a denúncia, garantindo-se, na forma da Lei, o direito de sigilo.

$\S 2^{\varrho}$ - Recebida a denúncia, competirá à Secretaria Municipal de Atividades Urbanas a lavratura do auto de infração.

Art. $6^{\circ}-\mathrm{O}$ auto de infração a que se refere o artigo anterior deverá ser impresso, numerado em série, preenchido de forma clara e precisa, sem emendas, rasuras ou entrelinhas, e conterá as seguintes informações:

I - local, data e hora da lavratura;

II - nome, endereço e qualificação do autuado;

III - a descrição do fato ou ato constitutivo da infração;

IV - o dispositivo legal infringido;

V - a notificação para apresentação de defesa no prazo de 10 (dez) dias;

VI - a identificação do agente autuante, contendo sua assinatura, cargo ou função e o número da matrícula;

VII - a assinatura do autuado.

$\S 1^{2}-\mathrm{A}$ assinatura do autuado no auto de infração constitui notificação, para efeito do disposto no inciso $\mathrm{V}$ deste artigo, devendo, na contagem do prazo, ser excluído o dia primeiro dia útil se cair em feriado, se cair em feriado, sábado ou domingos.

$\S 2^{2}-$ Se o autuado recusar-se a assinar o auto de infração, o agente autuante consignará o fato no próprio documento, remetendo-o, via postal ao autuado, com aviso de recebimento ou do outro procedimento equivalente, que valerá como notificação. 
$\S 3^{2}-$ Quando o infrator não puder ser notificado pessoalmente ou por via postal será feita a notificação por edital divulgado na imprensa oficial do município.

Art. $7^{2}-\mathrm{O}$ autuado poderá apresentar defesa, no prazo de 10 (dez) dias, contados da notificação, indicando as razões de fato e de direito que fundamentaram sua impugnação e as provas que pretende produzir.

Art. $8^{\varrho}$ - Decorrido o prazo mencionado no artigo anterior, com ou sem impugnação, os autos serão remetidos à Secretaria Municipal de Negócios Jurídicos, que determinará as diligências cabíveis e as provas a serem produzidas, podendo requisitar, do autuado e de quaisquer entidades públicas ou particulares, as informações e os documentos imprescindíveis à elucidação e decisão do caso.

Art. $9^{\circledR}$ - Caberá à Secretaria Municipal de Negócios Jurídicos, após apreciar a defesa apresentada pelo autuado, o julgamento do processo administrativo.

Parágrafo único - A decisão administrativa deverá conter o relatório dos fatos, os fundamentos de fato e de direito e o dispositivo infringido.

Art. 10 - Julgado o processo, o autuado será intimado da decisão no prazo de 05 (cinco) dias.

$\S 1^{\circledR}$ - Da decisão condenatória, caberá recurso, em última instância, com efeito suspensivo, ao Prefeito Municipal, no prazo de 10 (dez) dias, contados da intimação da decisão.

Art. 11 - As penalidades impostas aos que praticarem atos de discriminação, por qualquer dos motivos elencados no artigo $2^{2}$ desta Lei, ou qualquer outro que seja atentatório aos direitos e garantias fundamentais da pessoa humana, serão as seguintes, aplicadas progressivamente da maneira a seguir:

I- advertência;

II - multa de 1.000 (um mil) UFIRs;

III - multa de 3.000 (três mil) UFIRs, em caso de reincidência;

IV - suspensão do alvará de funcionamento por 30 (trinta) dias;

$\mathrm{V}$ - cassação do alvará de licença e funcionamento.

$\S 1^{2}-$ As penas mencionadas nos incisos II, III, IV e V, deste artigo, não se aplicam aos órgãos e empresas públicas, cujos responsáveis serão punidos na forma do Estatuto dos Servidores Públicos Municipais.

$\S 2^{2}$ - A capacidade econômica do estabelecimento infrator poderá ser levada em consideração, na aplicação das penalidades ora estabelecidas.

$\S 3^{\circ}$ - Os valores das multas previstas nos incisos II e III deste artigo poderão ser elevados em até 10 (dez)vezes quando for verificado que, em razão do porte do estabelecimento, resultarão inócuos.

$\S 4^{2}-$ Quando for imposta a pena prevista no inciso V supra, deverá ser comunicado, imediatamente, o órgão expedidor do respectivo alvará de funcionamento, a quem compete cassá-lo; 
$\S 5^{\Omega}$ - Em caso de ação ser praticada por pessoa física, o Poder Público, através do órgão competente, imediatamente oferecerá denúncia ao Ministério Público.

Art. 12 - Aos servidores públicos municipais, no exercício de suas funções e/ou em repartição pública que, por ação ou omissão, deixarem de cumprir os dispositivos da presente Lei, serão aplicadas as penalidades cabíveis nos termos do Estatuto dos Servidores Públicos Municipais.

Art. 13 - O conhecimento de situação que afronte as garantias previstas nesta lei, ou seja, quando ocorra qualquer tipo de discriminação contra o cidadão, acarretará independentemente de denúncia da vítima, a lavratura imediata de auto de infração, dando-se início ao competente processo administrativo, no qual será assegurada ampla defesa.

Art. 14 - O Município criará o Centro de Referência para a Defesa e Valorização da Auto-Estima e Capacitação Profissional do Cidadão Homossexual, bissexual e transgênero, de forma a permitir a sua inserção com dignidade e respeito no ambiente social e o combate às ações de natureza homofóbicas.

Art. 15 - Cópias desta Lei serão, obrigatoriamente, distribuídas pelo município e afixadas pelos estabelecimentos em locais de fácil leitura pelo público.

Art. 16 - Esta Lei entra em vigor na data de sua publicação, revogadas as disposições em contrário.

Paço da Prefeitura de Juiz de Fora, 12 de maio de 2000.

a) TARCÍSIO DELGADO - Prefeito de Juiz de Fora.

a) GERALDO MAJELA GUEDES - Secretário Municipal de Administração.

[CMJF - Câmara Municipal de Juiz de Fora] [iS@L] 